be available in all United Nations official languages. The 'Orange Book' is supplemented by a 'Manual of tests and criteria' for the classification of goods to be transported. A second revised edition of this Manual will be issued soon.

The Recommendations are prepared by the Committee of Experts on the Transport of Dangerous Goods, a subsidiary body of the Economic and Social Council (ECOSOC) which is serviced by the secretariat of the United Nations Economic Commission for Europe (ECE). The ECE is also responsible for the elaboration of legal instruments regulating transport of dangerous goods by road, rail, and inland waterways, in its Region (Europe and North America).

\author{
UNITED NATIONS INFORMATION SERVICE \\ UN/ECF Information Office \\ Palais des Nations \\ CH-1211 Geneva 10 \\ Switzerland.
}

Tel. (022) 9172893

Fax (022) 9170036.

\title{
Short Courses on Life-zone Ecology and Tropical Dendrology
}

$\mathrm{T}_{\mathrm{s}}^{\mathrm{h}}$ The classification of the Earth's ecosystems and ecocomplexes affects almost all ecological and geographical science. Additionally, the identification of plants is closely related to the classification of ecosystems which on land are largely characterized by their plant components. From an academic perspective both these subjects are crucial, as they form the basis for sustainable resource management and biodiversity preservation.

Dr L.R. Holdridge's Life-zone Ecology classification system and Tropical Dendrology (a system to identify forest trees) have been used by scientists and other professionals in the tropics for more than 30 years. Furthermore, based on the Life-zone Ecology system, several practical and sound applications have been developed by the Tropical Science Center to be used in rural development, sustainable resource management, watershed management, land-use capability, assessment of environmental impact, territorial zoning, and ecosystem characterization in protected areas.

Recently, the US National Atmospheric and Space Agency (NASA) prepared an earth map of life-zone ecosystems which has been used to monitor and predict vegetation changes due to increase of atmospheric $\mathrm{CO}_{2}$ (a leading basis of the so-called 'greenhouse effect'). Also, in 1992, the World Conservaton Monitoring Centre (WCMC) gave strong support to the Holdridge Life-zone system by including it in their official publication Global Biodiver- sity: Status of Earth's Living Resources. WCMC is jointly directed by IUCN, UNEP, and WWF.

Through participation in the Life-zone Ecology course, students should have gained enough knowledge to implement sound, practical applications of the system on such activities as are mentioned in the preceding paragraphs. After attending the Tropical Dendrology course, students should be fully accomplished at identifying a large proportion of tropical trees and shrubs, including their family, genus, and in some cases species. Course participants will also gain special skills that should enable them to continue making progress on their own upon returning to their respective countries.

Courses last 3 weeks each and will be offered consecutively during the first semester every year. Costs are US $\$ 2,500$ for Tropical Dendrology and US $\$ 2,700$ for Lifezone Ecology (please note that these amounts do not include airfares). For any further information please contact:

Dr HumBERTo JimÉnEz SAA
Tropical Science Center
PO Box $8-3870$
San José 1000
Costa Rica.
Phone: 5062252649
5062533267
Fax: $\quad 5062534963$

\section{RELIEFNET: A Step Towards an Integrated Emergency Information System}

$\mathrm{T}$ The United Nations Department of Humanitarian Affairs (DHA) has recently provided a sample of what the international community can expect from a global system to manage information on complex emergencies and natural disasters. RELIEFNET, a network to allow real-time transfer and dissemination of information, received a test run of its online distributed information system via INTERNET, during a high-level two-days' meeting attended by representatives of governments, INGOs, and NGOs.

RELIEFNET's primary objectives are to enhance decision-making within governmental and humanitarian agencies and to improve the effectiveness of humanitarian assistance, particularly through the flow of critical information. 'Reliefnet is conceived as a decentralized system, built precisely to take advantage of the strengths of existing systems, in full recognition of the expertise and requirements of different but equal partners', says UN UnderSecretary-General for Humanitarian Affairs and Emergency Relief Coordinator Mr Peter Hansen, who chaired the meeting, adding that 'The sharing of timely information is critical to facilitate coordination and cooperation'.

RELIEFNET has to take into account not only the different needs of potential users, such as confidential transfer of sensitive information, but also the different computer systems which they use. Rather than duplicate existing networks, RELIEFNET will bring them together to build up a multifaceted picture of emergency situations.

An international discussion of RELIEFNET in Washington, DC, some months ago indicated that the international community supported the concept of an integrated international emergency information system, but this meeting in June was the first opportunity since then for participants to review the process. For further information please contact:

MADELEINE MOULIN-ACEVEDO
Information Service
United Nations Office at Geneva
Palais des Nations
CH-1211 Geneva 10
Switzerland.

Tel. 41229172856. 